\title{
電動アシスト自転車用超磁歪トルクセンサの開発
}

\author{
正員 角谷 和 重 (三洋電機株式会社) \\ 正 員 横 谷 和 展 (三洋電機㧣式会社)
}

\section{Development of a Torque Sensor using Giant Magnetostrictive Material for Electric Power-Assisted Bicycles}

\author{
Kazushige Kakutani, Member (SANYO Electric Co., Ltd) \\ Kazunobu Yokotani, Member (SANYO Electric Co., Ltd)
}

\begin{abstract}
We developed a new light-weight power-assisted bicycle using a giant magnetostrictive torque sensor, which is a new mechatronics product for individual use. The key components for power-assisted bicycles are sensors, which are vital for detecting the extremely large forces (maximum crank axle torque : about $160 \mathrm{Nm}$ ) of power exerted on the pedals by the riders. In this paper we propose a torque detection method that uses a giant magnetostrictive material with a high force detection sensitivity, where the capacity to resist stress is extremely large.

Improving the hysteresis has become an issue for raising the precision of force sensors that use giant magnetostrictive elements. As a method to improve the hysteresis, we focus on the point of integrating these force sensors into microcomputer-equipped digital control systems, and construct a detection circuit such that the magnetostrictive elements are expanded instantaneously by the application of a pulse magnetic field during the sampling of discrete sensor data. this paper also examines this hysteresis reduction method and reports the contents of an actual construction method for force sensors.
\end{abstract}

キーワード：超磁昰材料、磁歪、ヒラリ効果、トルタセンサ、ヒステリシス、パワーアシスト自軾車

Keywords : giant magnctostrictive material, magnetostriction, Villari Effect, torque sensor, hysteresis, power-assisted bicycle

\section{1. まえがき}

高齡化社会, 環境問題を背景に近年注目を集めている電 動アシスト自転車は，人間がペダルを踏む力(トルク)を 検出し，その情報を基に駆動モータをトルタ制御する新し いタイプのパーソナルコミュータである. 使用者はモータ 駆動部の操作方法を意識せずに通常の自転車と同じ感覚で 操縦するたりで，䄪半分の走行負荷をモータが補助する。 この補助割合を全駆動力の 50\%以下とすれば, ”通常の自 転車”として認められるため，取り扱いも簡単ということ で急速な市場形成も始まっている(1).

電動アシスト自転車のキーコンボーネントとして, 人間 のペダル踏力という非常に大きな力（最大クランク軸卜ル ク：約 $160 \mathrm{Nm}$ ）の検出を，自転車機構というシンプルで限 られたスペースにコンパクト且つ低コストで実現できるセ ンサが要求される。現在, そのセンサとしては, 力伝達系 に弾性要素を用い，機構を駆使した弾性変位量検出式卜ル クセンサが主に採用されている(2)(3).しかしこの方式で は，回転部で受ける力(弾性体の変位量)を機構的に固定部 へ伝達しているため構造が複雑で大きくなる．また，バネ 等の弾性変位で検出するため弾性係数が小さいとペダル作
動時に通常の自転車とは異なる違和感が生じる。

これらの課題を解決するためには, バネ等の弾性变位と 変位の伝達機構を用いない検出方法が必要である。著者ら は，強磁性体材料が圧縮応力により内部磁化が変化する磁 歪の逆効果に着目し，磁化の变化をコイル等を用いて電気 信号に変換することで，耐圧縮力が大きい金属材料を用い てダイレクトに力を榙出する手法を提案する。

磁歪現象は，強磁性体に磁場を加えると，磁化べクトル が磁場の方向に揃うように回転することで形状に変化を起 こす現象である。なかでも飽和磁歪が1000ppmを超えるよ うな材料を超磁歪材料 ${ }^{(4)(5)}$ (Giant Magnetostrictive Material GMM) と呼ぶ。また，エネルギ密度は $(2.3 〜 36) \times 10^{\mathrm{x}} \mathrm{J}$ mであり，压電材料に比べて10～50倍と大きいことから， 海洋ソナ一等の開発目的で1959年から米国海軍戦略研究 所のA.E.Clarkらによって研究が進められてきた ${ }^{(6)}$.しか し，民生用への応用開発は歴史も浅く，以上の特徴を生か した特定用途のアクチュエータとして開発(6) -(8) があるも のの七ンサとしての民生応用は報告がない，国内で唯一超 磁歪材料の製造を行っているTDK(株)から压力センサ (9)や 振動センサ(10)の報告にみられる程度である。その理由の一 つとして, 超磁歪材料は, 強磁性材料がもつ磁気とステリ 
シス特性が大きい点が挙げられる。アクチュエータとして 用いる場合は，歪み量等のフィードバックにより出力変位 の制御が可能であるが，七ンサの場合は，そのヒステリシ 又特性がセン㤢性能に直接影響を与える。

しかし，磁化の变化による寸法变化量が大きいことは， 大きな外部応力に上万内部磁化の変化量も大きく，磁化 (または, 透磁率) 検出用コイルを用いると, 検出可能な力 の範囲で大きな電気的インピーダンス変化が得られるため, 大応力用の高感度なデバイスの構成が期待できる.

そこで本研究は，超磁歪材料を用いた電動アシスト自転 車用トルクセンサを開発し，そのセンシング性能を評価し た。また, 高精度化の最大の問題点となるヒステリシス現 象についても考察を行い, 超磁歪セン卅の民生応用として マイコン搭載機器への組込みを考虑したヒステリシス低減 手法を提案し，その特性と効果ついても検証した。

\section{2. 電動アシスト自転車}

〈2・1〉 全体構成図 1 に電動アシスト自転車の概念 図を示す。トルクセンサは，人間が自転車に与えるペダル 踏力トルタをリアルタイム (数msでサンプリング)に検出す るものである。パワーアシストコントローラは，この検出 トルクに対してアシスト率(人間の踏ノトルクに対する補助 動カトルクの比率) $100 \%$ 以内で，モータにより自転車の駆 動トルクを補助している。即ち，人間が自転車を漕いでい る状態では，踏力センサによりその踏力トルクを検出し，

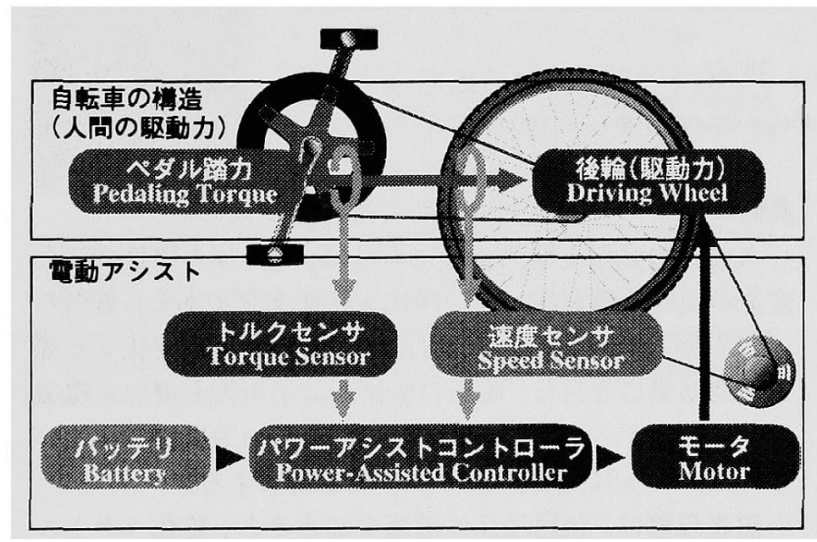

図 1 電動アシスト自転車の概念

Fig.1. Concept of the electric power-assisted bicycle

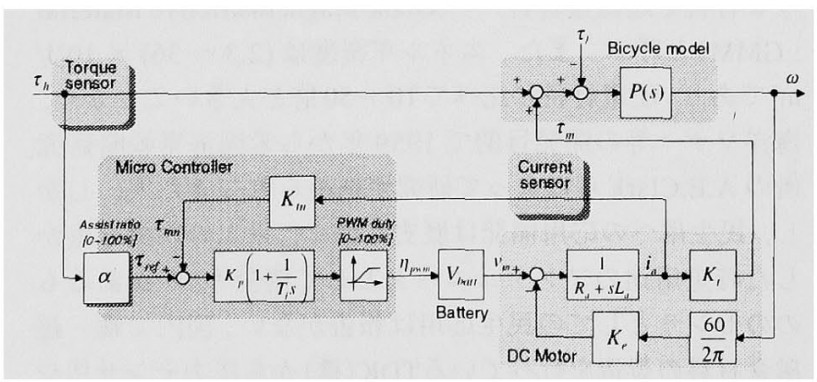

図 2 電動アシスト自転車の制御ブロック図

Fig.2. Block diagram of a electric power-assisted bicycle
最大で踏力トルクと同等の補助トルクをモータが出力する ため，アシストのない場合と同じ条件の負荷に対し，約半 分の踏力となる．入力となる人間の踏力トルクがゼロの場 合，アシスト率に関倸なくモータは補助卜ルクを一切出力 しない。しかし，操作上は，モー夕の駆動を意識する必要 がなく，徉来の自転車と全く同じであることが大きな特徴 である。

図 2 に開発した電動アシスト自転車の制御ブロック図を 示す.ここで, $P(s)$ は人間が搭乗した自転車モデルで駆動卜 ルク入力により駆動輪の回転速度を出力する。ブロック図 では便宜上モータから駆動輪までの減速比を考慮したモー 夕軸の回転速度 $\omega$ を自転車モデルの出力としている， $\tau_{h}$ は 人間の踏カトルク， $\tau_{m}$ はモータによる補助トルク，神は自転 車が受ける負荷トルク， $\tau_{m n}$ はモー夕仕様にあるトルク定数 $K_{t n}$ と電流センサによる電機子電流值 $i_{a}$ から求められる計算 上のモータ補助トルクである。 $\tau_{\text {ref }}$ は踏カトルクセンサより 得られたトルク值にアシスト率を掛けPI補償器への指令值 としたものであり， $K_{p}$ は比例ゲイン,$T_{i}$ は積分時間を表す. モータへの印加電圧は PWM(Pulse Width Modulation)によ

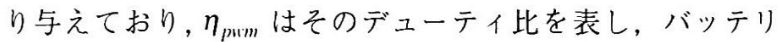
電圧値 $V_{\text {batr }}$ によりモータ電圧 $V_{m}$ が与えられる.DCモータは 電機子抵抗 $R_{a}$, インダクタンス $L_{a}$ から得られる一般的なモ デルである。制御装置は，トルクセンサ情報をパラメータ とした適切なアシスト比率でモータ出力をトルク（電流 フィードバック）制御している。電動アシスト自転車が通 常の自転車の範疇であるためのレギュレーションとして, 車速に対するアシスト率の制限がある。車速が $15 \mathrm{~km} / \mathrm{h}$ まで は、アシスト率 $100 \%$ まで可能であるが, $15 \mathrm{~km} / \mathrm{h}$ から $24 \mathrm{~km} /$ $\mathrm{h}$ までアシス卜率は比例漸減し， $24 \mathrm{~km} / \mathrm{h}$ 以上では $0 \%$, 即ち モータによる補助を行ってはいけない，図1における速度 センサはこの用途で搭載されている，以上のパワーアシス ト制御に扔いて，より人間に快適なアシスト感を実現する ためには，現状のレギュレーションであるアシスト率 100\% 以内でどのようにアシスト力を制御するかが課題となる. その前提として制御系の入力となる踏力トルクの良好なセ ンシング性能が要求される(11). 本開発での設計思想として は, 従来のシンプルな自転車構造をできる限り变更するこ となく小型軽量な電動アシスト自転車を実現するために， トルク検出系とアシスト駆動系を独立に設計できるものと する。

〈2・2〉踏カトルクセンサ＼cjkstart現在, 既に商品化されてい る各社電動アシスト自転車の機構式踏力トルクセンサの一 般的な構成を図 3 に示す。現行の電動アシスト自転車は, モー夕出力軸からの合力機構も考慮して, その殆どが専用 フレームを採用し, ペダルが取り付けられているクランク 部にトルクセンサ機構を組み込んでいる。基本的構成は， 無限回転するクランク軸とチェーンホイールの間に伝達卜 ルクに応じて変位する弾性体を介在し，このトルクに応じ た回転部での変位量をカムや遊星ギア等の機構を駆使して 


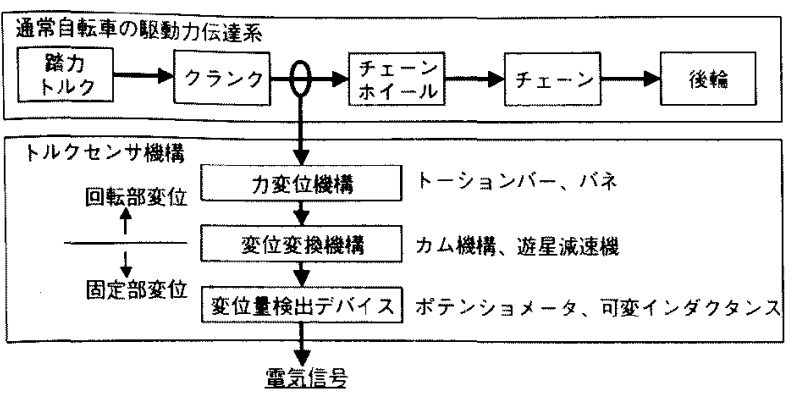

图 3 機構式踏カトルクセンサの一般的構成

Fig.3. Block diagram of a electric power-assisted bicycle

固定部での変位量に変換する。この变位量をポテンショ メータや可変インダクタンス, 可変容量を用いて電気信号 に变換し，人間の踏力トルクとの相関を求めることでセン サとして機能する。主な例としては，ペダル踏力トルクの 入力からチェーンホイールまでのトルク伝達機構に遊星歯 車機構を採用し，入力軸を遊星蒾車のプレート回転軸，出 力軸を外歯車とし，その間の伝達卜ルクの反力を受ける内 菌車の回転をバネにより抑制する構成をとるものがある(2). これにより，遊星菊車から外歯車まで卜ルクが伝達される ときの反力をこの回転抑制バネが受けることになり，伝達 トルクに比例してバネが押し縮められる。このバネの変位 量をポテンショメータで抵抗值の変化として検知寸る。ま た，別な方法として，クランク軸にトーションバーを採用 し，トルクに応じた捻れ量をカム機構を用いてクランク軸 と平行方向の変位に変換し，この変位量を直動式ポテン ショメータで抵抗值の変化として検知している例もある(3). このときのクランク軸の捻れ量は, $100 \mathrm{Nm}$ で $5^{\circ}$ といった 設計になっている，以上の例に示す機構は，自転車の簡単 な機構に対して極めて複雑な構成である。

本研究では、これら弾性変位量検出式トルタセンサとは 違う方式として，超磁歪素子によりカをダイレクトに検出 する超磁歪トルクセンサを開発した。

\section{3. 超磁歪素子を用いたトルクセンシング}

<3-1> 超磁昰材料と伈力検出原理超磁歪材料は, 磁 気モーメント，磁気弾性エネルギーの大きいランタノイド

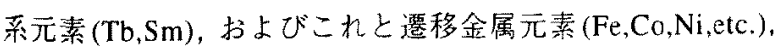
との 2 元系立方晶 $\mathrm{RT}_{2}$ ( $\mathrm{R}:$ ランタノイド， $\mathrm{T}:$ 遷移金属元素)， さらに低磁界駆動を実現するために磁気異方性を下げた擬

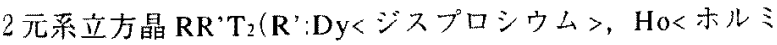
ウムっなど)を示し, 現在, 擬 2 元系の $\mathrm{Tb}_{0.3} \mathrm{Dy}_{0.3} \mathrm{~T}_{2}$ が商品化 されている(4)。磁場に上る磁化の過程に伴う飽和磁歪は, 鉄 やニッケルがせいぜい数十 ppmであるのに対し，超磁歪材 料は1000～2000ppmの飽和磁歪をもつ材料である. 表 1 に 現在入手可能な超磁歪材料の諸物性(4)(5)を示す. 磁界の印加 により磁歪が起こる現象を磁歪効果といい，逆に機械的歪 みに上り内部磁化が变化する現象を磁歪の逆効果という。 磁歪に㧍ける電気(磁気) エネルギーと機械エネルギーの変
表1 超磁歪材料の諸物性

Table 1. Nominal properties of GMMs

\begin{tabular}{|c|c|c|c|}
\hline 材料名 & PMS-1 & PMT-1 & Terfenol-D \\
\hline 製造元 & \multicolumn{2}{|c|}{ TDK } & ETREMA \\
\hline 製造方法 & \multicolumn{2}{|c|}{ 粉末冶金法 } & ブリッジマン法 \\
\hline 磁整童 (ppm) & $1450(\mathrm{H}=3 \mathrm{kOe})$ & $1450(\mathrm{H}=3 \mathrm{kOC})$ & $1500^{\sim} 2000$ \\
\hline I礼ギー密度 $(\mathrm{kJ} / \mathrm{m}$ “3) & 10 & 10 & $14^{\sim} 25$ \\
\hline 発生応力 (N/cm 2) & $3900(\mathrm{H}=3 \mathrm{kOe})$ & $3900(\mathrm{H}=3 \mathrm{kOe})$ & - \\
\hline 密度 $\left(\mathrm{kg} / \mathrm{m}^{\prime} 3\right)$ & 7,950 & 7.950 & 9,250 \\
\hline ヤング率 $\left(\mathrm{N} / \mathrm{m}^{2} 2\right)$ & $2.0 \times 10+E 10$ & $2.0 \times 10+E 10$ & $2.5^{\sim} 3.5 \times 10+\mathrm{E} 10$ \\
\hline 王縮強度 $\left(\mathrm{N} / \mathrm{m}^{\prime} 2\right)$ & $600 \times 10+E 6$ & $600 \times 10+E 6$ & $700 \times 10+E 6$ \\
\hline 引張り強度 $\left(\mathrm{N} / \mathrm{m}^{\prime} 2\right)$ & $20 \times 10+E 6$ & $20 \times 10+E 6$ & $28 \times 10+E 6$ \\
\hline 電気抵抗 $(\Omega \cdot m)$ & $60 \times 10-E 8$ & $60 \times 10-E 8$ & $60 \times 10$ E8 \\
\hline 比透磁率 & 8 & 6 & 9.2 \\
\hline
\end{tabular}

換基本式は，ある操作点近傍の線形領域に扔いては次式で 与之られる。

$$
S=s^{H} T+d H
$$

$B=d T+\mu^{T} H$

ここで， $S:$ 歪み, $H$ : 磁界强度, $s^{H}$ : 弾性コンプライ アンス(ヤング率の逆数)， $d:$ 磁歪定数， $B$ : 磁束密

度, $T$ : 機械的応力, $\mu^{T}:$ 応力 $T$ 時の透磁率である ${ }^{(12)}$.

(1)，(2)式より，印加磁界に対する磁歪量が大きい材料で は，機樴的応力に対する磁化の変化も大きく超磁歪素子を 用いると感度の高い力センサを構成することができる．ま た，金属材料であるため，表にに示すように素子の压縮強度 は非常に高く小型軽量な力七ンサが構成可能である。

図 4（a）に本トルタセンサに井いた超磁企素子(TDK 製： PMT-1， $\phi 8 \times 7.5 \mathrm{~mm})$ の外観を示寸。製造方法加ら，粉末 治金法による燒結材料(TDK製)とブリッジマン法による単 結晶材料(米国エトリーマ社製) の大きく2つの材料が入手 可能である。単結晶材料 Terfenol-Dは，焼結材料上り更に 压縮強度が高く，主にアクチュエータとして様々な応用が なさ机ているが，円柱形等の組込みに適した形状を要求す るとコス卜高になる。これに対しTDKによる粉末治金法で は，独自の金型設計により，低コストな素子の製造が可能 となってきている，本センサは，焼結材料を用いた，

超磁歪素子による応力検出は, 前述のビラリ効果を検出 原理としている，磁化の検出は，(1素子に巻いたコイルの 自己インダクタンスの変化, (2)差動変压器の2つの)腕の磁 心での磁化のそれぞれの増隇，(3)磁気ブリッジ回路の4つ の腕の不平衡などで行える(13)。本センサでは，機構的に最 も簡単な(1)の手法を用いる。図4(b)に検出原理図, 図 4 (c) に今四設計した応カピックアップ部の外観を示す.

〈3・2〉王樎力によるインダクタンス特性図4(c)の 検出コイルは, 図 4 (a)に示す素子に線径： $\phi 0.15 \mathrm{~mm} の$ UEW 線を内径: $10.0 \mathrm{~mm}$, 外形: $14.5 \mathrm{~mm}$, 長さ $7.5 \mathrm{~mm}$ で巻数 400 ターン巻いたものである。一般的に,このようなコイルの 


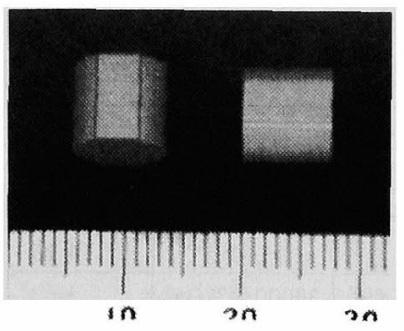

(a) 超磁歪素子の外観

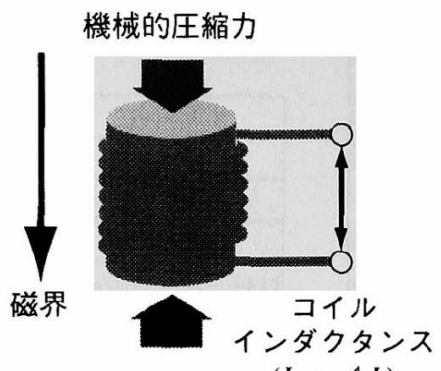

$(L+\Delta L)$

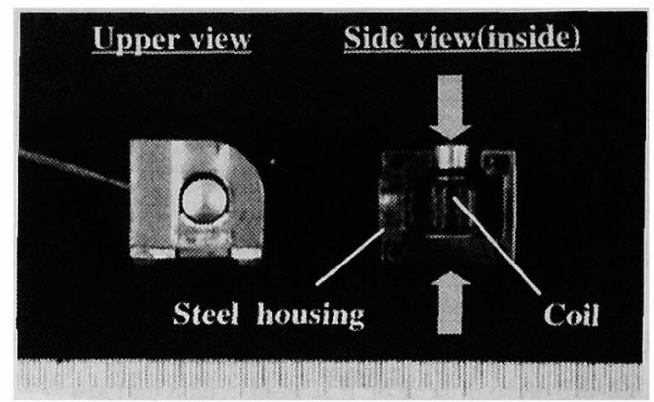

(c) カピックアップ部(試作品) の構造

(b) ビラリ効果 (Villari Effect)

図 4 超磁歪素子とこれを用いたカピックアップ部の外観および検出原理

Fig.4. Principle of force detection and outside view of a force pick-up using GMM

インダクタンス $L$ は，次式で表される。

$L=k \cdot \mu^{(T=0)} \cdot N^{2} \cdot A / I$

ここで, $k$ : 長岡係数, $\mu^{f \neq}:$ 応力 $T$ がゼロの時の超 磁歪素子の透磁率, $N$ : コイルの巻数, $A$ : 素子の 断面積, $l$ : 素子長である.

(3)式より, 透磁率の変化は, コイルの自己インダクタン ス変化として検出される，透磁率 $\mu$ は，素子に加わる応力 $T$ の関数であり, 正と負のビラリ効果をもつ.ここでは, 正 のビラリ効果を物質が圧縮されたときに透磁率が減少する ことと定義する．また，外部からの磁気ノイズの抑制や，漏 れ磁束を少なくする目的で図 4 (c) に示すように素子とコイ ルの周辺には鉄 (S45C) 製のヨークで磁束経路を形成してい る.このときカピックアップの自己インダクタンス变化は, 検出のための励振周波数に依存する。図 5 にカピックアッ プの無負荷と $4000 \mathrm{~N}$ 負荷 (圧縮力)におけるインダクタンス 変化量と励振周波数との関係を示す、周波数が $1 \mathrm{kHz}$ をこえ るとインタクタンスが急激に小さくなり，20kHz 以上では 負荷に対する変化が殆どなくなる。これは，コアとなる超 磁歪材料が鉄を主とする組成の合金であるため抵抗率が小 さく, 高い周波数帯域ではそれによる渦電流の影響が大き

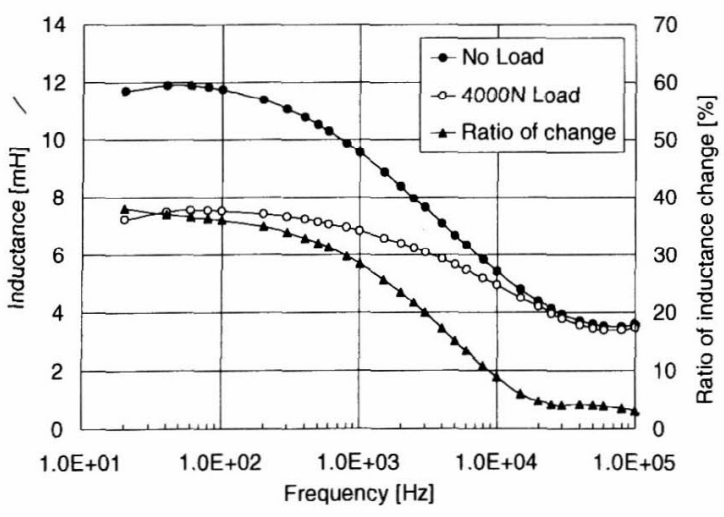

図 5 インダクタンスの周波数特性

Fig.5. Frequency characteristics of inductace
くなるためである。しかし, 超磁歪素子単体では, $10 \mathrm{kHz}$ 付 近まで影響は少なく，ここでの低下はヨーク部が鉄である ことの影響が大きいと考えれられる。また，インダクタン ス $L$ は磁束 $\phi$ とコイルの電流 $i$ を用いて次式でも表される.

$$
L=d \phi / d i
$$

$4000 \mathrm{~N}$ 負荷は, 磁歪の逆効果において, ほぼ飽和の圧縮応 カであり,インダクタンス測定のための微小電流 $i$ 変化に 対する磁束 $\phi$ の変化が無負荷時よりも小さくなり，渦電流 の影響が抑えられることで, 高い周波数領域までフラット な特性を示している。

以上より, 静的な荷重計測でセンサの感度のみを考える と励振周波数は低く設定するとよいことになるが，ここで は, センサとしての応答性や無負荷時のコイルインダクタ ンスと巻数の関係を考慮して, 本センサの励振周波数を $4 \mathrm{kHz}$ と設定した。

く3·3〉超磁䄳トルクセンサの樌成 人間が加える踏力 トルクを知るためには, ペダルから後輪までの力伝達過程 のどこかでその伝達力 (トルク)を検出すれば良い. 提案す るトルクセンサは, センサのユニット性を考慮し, 超磁歪 素子を用いた力ピックアップ部が小型化可能なことから， クランク部のチェーンホイールに内蔵した。ホイールがク ランク軸とチェーン間で受ける力を検出することでトルク 值を計算により求める. 図 6 (a)にトルクセンサ概略構成の ブロック図を示す．構成は, 内ホイールと外ホイールが独 立して自由回転するように構成し, 内ホイールがペダルク ランク及びクランク軸に固定される．回転中心から一定の 腕の長さをもった位置で, 図 4 (c) に示すカピックアップが 各ホイール間で挟まれるように配置し，ペダル踏力と チェーン負荷により超磁歪素子が圧縮力を受けるような構 造となっている。検出回路は, スリップリングを通してコ イルに一定周期の電圧を印加し, コイルのインダクタンス 変化による電流值変化を検出する. 電流值は, 電流検出用 に挿入したシャント抵抗器の電圧降下により検出し, その 


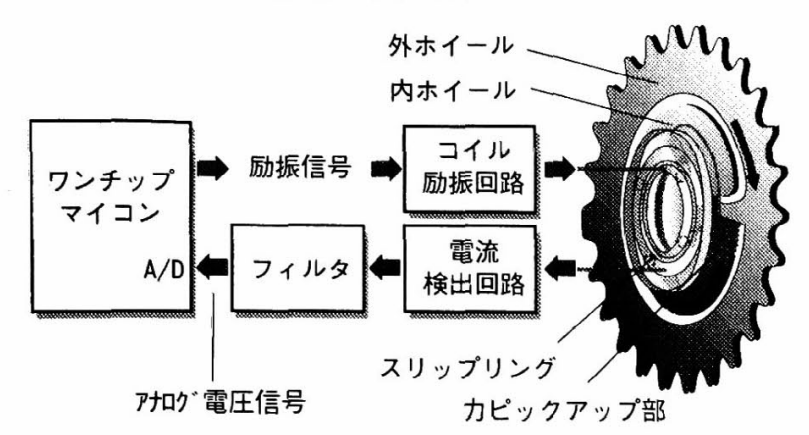

(a) 超磁歪トルクセンサのブロック図

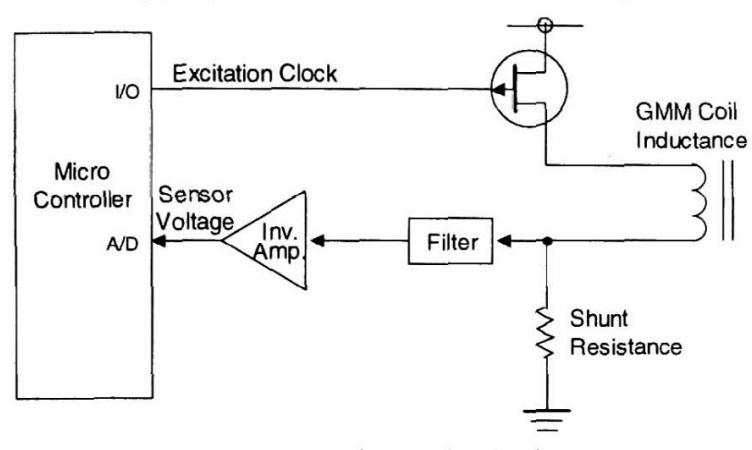

(b) 検出回路の概略

図 6 超磁歪トルクセンサの概略構成図

Fig.6. Schematic of GMM torque sensor

電圧値を反転増幅器により増幅した後にA / D コンバータ を通してマイコンに取り込む。堌幅器は，回路の都合上反 転増幅器を採用しており，結果的に以下の実験でのセンサ 出力はインダクタンスの変化と同じ極性となっている. 図 6 (b) に検出回路の概略を示す.

〈3.4〉超磁歪トルクセンサの基本特性 図 7 に超磁歪 トルクセンサの静的な負荷トルクに対するセンサ検出特性 を示す。センサ出力にヒステリシス(表2 参照)が見られる が，アシスト自転車用踏カトルクセンサとしてはアシスト 比率に関する制約を考虑すると十分な特性である。長所と

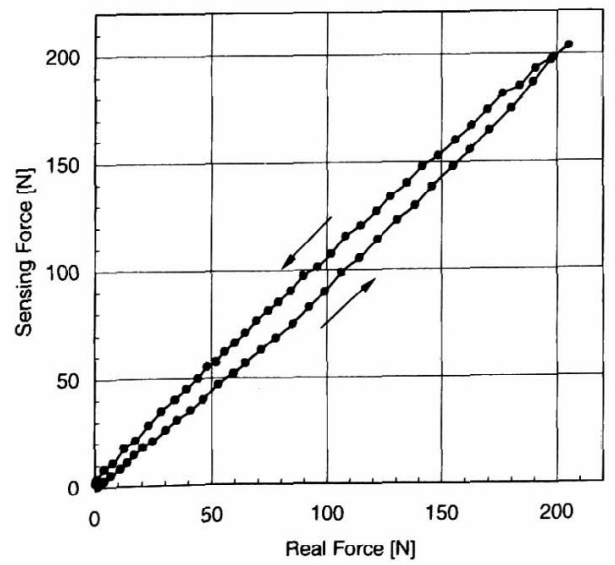

図 7 超磁歪トルクセンサの静特性 Fig.7. Characteristic of GMM torque sensor
表 2 超磁歪トルクセンサの性能 Table 2. Torque sensor performance

\begin{tabular}{|l|c|}
\hline \multicolumn{1}{|c|}{ Quantity } & Value \\
\hline 1. Mesurement range & $0 \sim 160 \mathrm{Nm}$ \\
2. Non-linearity & $\pm 5.0 \% / \mathrm{F} . \mathrm{S}$. \\
3. Hysteresis & $8.0 \% / \mathrm{F} . \mathrm{S}$. \\
\hline \hline
\end{tabular}

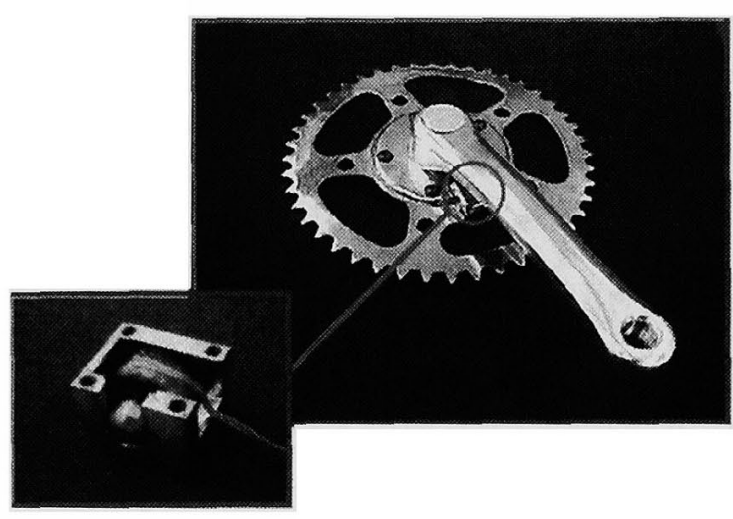

図 8 電動アシスト自転車用

超磁歪トルクセンサ(試作品)

Fig.8. GMM torque sensor for power-assisted bicycle

しては,小型軽量性をみると $100 \mathrm{~N} / \mathrm{m}$ 以上のトルクセンサで は工業用トルク検出器と比較して䄪 $1 / 10$ 程度のサイズと なっており，量産時のコストにおいても1/100程度での実現 が見达める.図 8 に今回試作したチェーンホイール内蔵の 電動アシスト自転車用トルクセンサの外観を示す．

\section{4. ヒステリシス低減手法の提案と検証}

〈4・1〉ヒステリシスの検証と考察超磁歪トルクセン サの特性は, 主にカピックアップ部のセンサ特性であり， 以下では,このカセンサ部特性を評価する.図 6 (b) の検出 回路を用いた超磁歪力センサ出力特性の測定装置構成図を 図 9 に示す。加圧装置には，60WDCモータとハーモニック ギア等による1/330減速機を用い, 直接センサに圧縮応力を

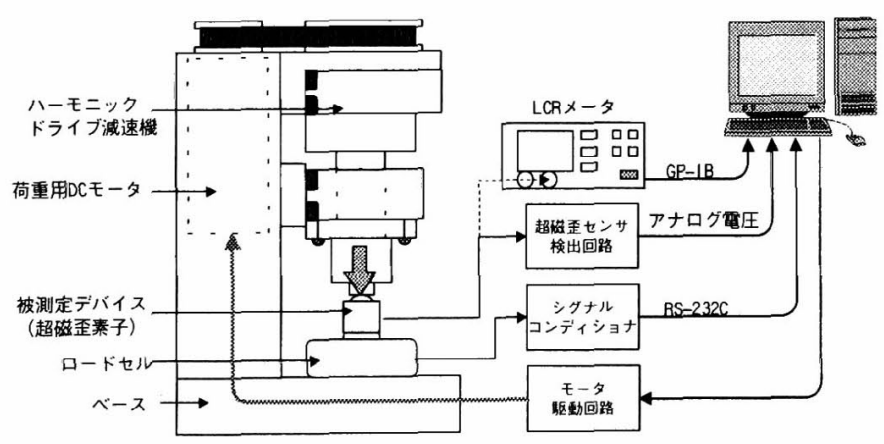

図 9 測定装置の構成図

Fig.9. Schematic daiagram of a measuring setup 
加える。実荷重は, 被测定センサの下部に高精度計測用 ロードセル（検出範囲：200kgf，非直楾性：0.05\%RO, 七 ステリシス：0.04\%RO)を配置し，校正されたシグナルコン ディショナで計测した值をRS232Cシリアル通信によりバ ソコン上で管理している。インダクタンスの測定では、検 出用コイルの両端にLCR ータ（HP社製：HP4284A）を接 続し，GPIBインタフエースを用いてデータ計湘を行った。

実験に用いた超磁歪材料は，粉末治金法によるTDK製 PMS-1で形状は， ф $3.5 \mathrm{~mm} \times 6.0 \mathrm{~mm}$ を用いた。検出コイル の仕様は, 内径: $5.5 \mathrm{~mm}$, 外形: $9.6 \mathrm{~mm}$, 長さ $6.0 \mathrm{~mm}$, 線径： $\phi 0.23 \mathrm{~mm}$ のUEW 線, 巻数: 200 ターンとした. 磁性体ヨー クは，S45Cで磁気経路を形成した，検出回路のアンブ增幅 率は150倍とし，七ンサ荷重と検出回路出力電王との相関 案験装置で测定する、測定条件は，素子の初期状態(荷 重, 磁化を一度も行っていない消磁状態) から $200 \mathrm{~N}$ まで加 压し，その後ゼ口荷重まで隇圧する，次に続けて同じサイ タルをもう2サイクル繰り返す：図10に測定結果を示す。 初期時状態加らの1サイクル目は，減压後初期の電圧值に 戻らず，2サイクル目以降は，その電圧值から1サイクル目 の200N加压時の電压值との間でヒシテリシスループを繰り 返す。

磁化による磁気とステリシス曲線は, 強磁性結晶内でマ グネトンが形成する磁壁と磁区が，印加磁場により磁区の 向きが磁界の方向に揃うように、磁壁の移動と磁区の回転 におけるピン止め現象に起因する，特に磁区の回転では形 状の変化も伴い磁歪効果となる.結晶内で拘束されていた 磁区が, 強磁場により一度回転が起きると, 印加磁場を 徐々に弱めても磁壁のビン止め現象により元の状態には戻 クにくくヒステリシスが生じる，磁区の持つ自発磁化の方

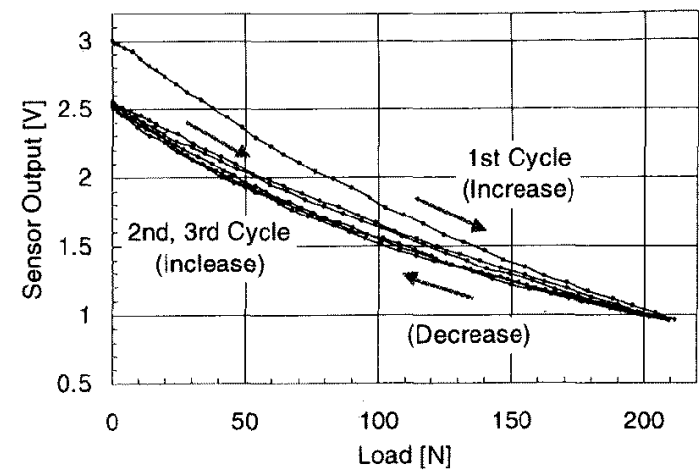

図10 センサ出力のヒステリシス特性

Fig.10. Hysteresis characteristics of detection circut

向は，一般にいくつかの磁化容易軸に向いており，結晶中 の磁区全体として各磁区の磁化は打ち消し合うように揃っ ている(図11(a))。この状態から，ある方向より圧縮力を加 えていくと結晶内の格子間隔のわずかな歪みにより，磁壁 や磁区を構成するマグネトンが回転し磁壁や磁区に変化が 生じ, 結晶中の磁化に变化を与える (図11(b)，(c))。一度変 化した磁区や磁壁は, 磁気ヒステリシス曲線と同様に加え る力を徐々に減らしていっても磁壁のピン止め，および， 回転した磁化べクトルのピン止めにより同じ経路で元の状 態には戻らず，図10に示すようなヒステリシスが生じると 考无られる(図11(d)).

〈4-2〉ヒステリシス低減手法の提案 前述の考察に述 ベた印加磁化や応力により生じた磁区の回転による残留磁 化を初期状態に戻す（消磁する）ためには，逆方向の適切な 強さの磁界または, 交流磁界を印加し, 強制的に残留磁化

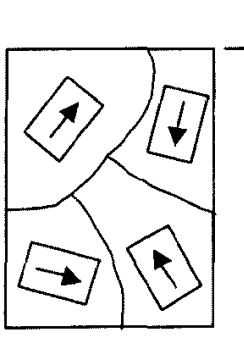

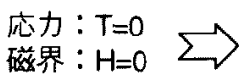
(a) 消磁状態

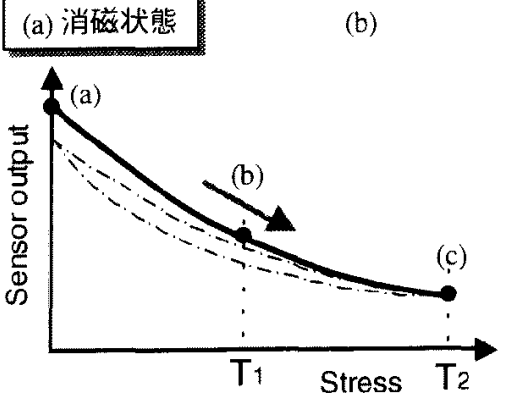

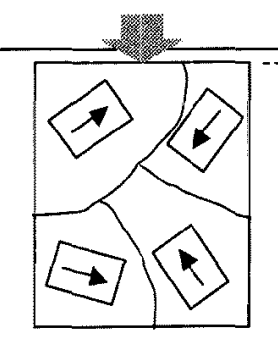

㐫力 : $T=T_{1}$ 磁界: $H=0$

(b)

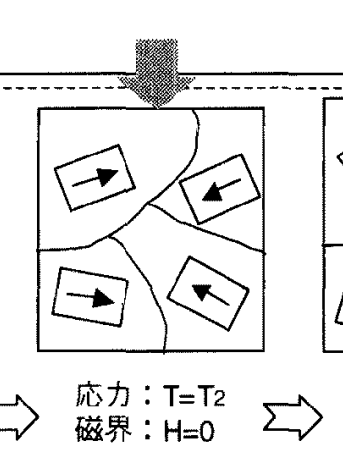

(c)

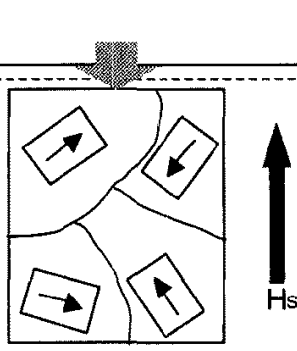

応力: $T=T$ 磁界 : $H=0$

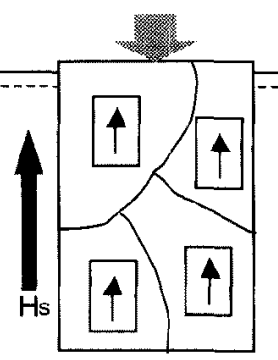

応力: $T=T_{1}$

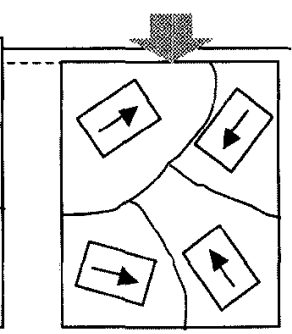

応力: $T=T_{1}$ 磁界: $\mathrm{H}=0$
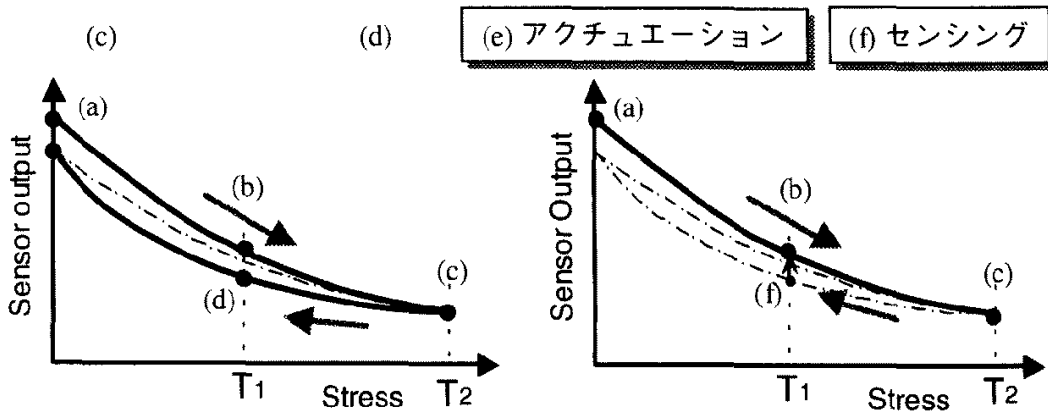

図11ヒステリシス低隇手法の概念図

Fig.11. Conceptual schematic for the proposed method of hysteresis reduction 
分を元に扈す必要がある、しかし，力センサとしての実用 を考えると小型大容量を長所とする超磁歪センサにおいて， 消磁に十分な交流磁界を常時印加するには，大きな消磁用 コイルを必要とし，小型化が困難になる。また，任意に変 化する応力に対して適切な逆磁界を求め印加することも容 易ではない。

そこで本提案では，力センサをマイコンによるデジタル 制御機器へ組込みこむことを考慮し，超磁歪材料が磁化に より寸法が伸びるアクチュエータとしての要素を, 時分割 によりセンサと同じ系で利用する。近年の組み込みシステ ムを用いたスマートデバイスの検出回路では，A/Dコンバー 夕等でセンサデータのサンプリングによる量子化を行うた め，データを離散值として扱うことが殆どである，そこで， 各サンプルの間に一時的にセンサ用の微弱な励振磁界より 十分に大きなパルス磁界を印加し，素子が伸びる方向に結 唱内の磁区の回転を生じさせる(図11(e))。これにより， データサンプル時は、検出する力の增隇にかかわらず，伸 びな状龍から圧縮方向のみで力を検出していることになり (図11(f)),センサヒステリシス曲線の初期状態からの曲線 のみを用いることになる。図11ではヒステリシス低隇手法 の一連の概念図を示している。このサイクルを時間的に十 分短くとると, マイコン検出回路も含む七ンサシステムと してヒステリシスが低減される(14)。

〈4-3〉検証実䮊図6(b)の検出回路にヒステリシス 低減のためのパルス電流印加回路を付加した回路図を図 12 に示す，ピーク電流值は，素子の消磁状態から力センサの 最大定格值にこの場合 $200 \mathrm{~N}$ )まで荷重を印加した徯に, 荷重 をゼロとした時に残る残留磁化を消磁状態まで戻せる磁界 相当の電流值を設定する。ここでは，試験的にピーク電流 値を $800 \mathrm{~mA}$ に設定している。測定装置及び被測定デバイス は，く4・1>と同じものを用いている。

〈4*4〉実験結果と考察本実験では, センサデータの

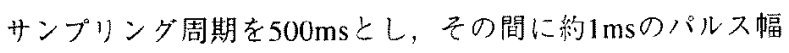
でパルス電流を流す。提案するヒステリシス低減手法を用 い，く4・1>と同一条件で測定を行った。センサ出力特性の测

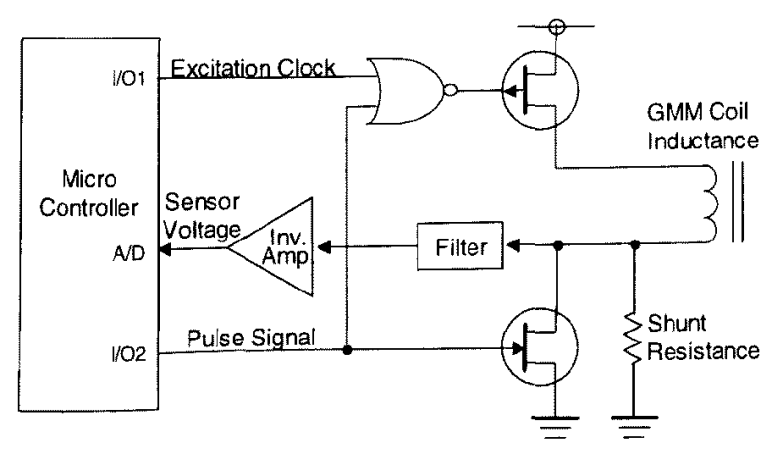

図 12 パルス電流回路付き検出回路の概要

Fig.12. Schematic of detection circuit with pulse current
定結果は，図沉示すようにヒステりシスの改善が見られ た，荷重ゼ口の状態では，パルス磁界により出力の初期值 が消磁状態とほほ同等の值を示す。荷重を增加するに従 い，検出回路の電圧は小さくなる方向に変化していくが, この時, 特性曲線は, パルス磁界を印加しない場合の消磁 状態からの初期曲線よりも大きな变化を示している。この現 象は，パルス磁界がゼロに戻る時の荷重による慣性力で七 ステリシス低隇手法を用いない状態より压縮歪が大きくな り，感度汃向上していると考えられる。しかし，実際に物 理的な素子の伸䌅があるため，磁界の立ち上り，立下り時 にインパルス音が発生する，特に立下り時のインパルス音 は大きい。この現象を起こさないようにするためには，パ ルス磁界の立上り，立下り侍間を十分に長く取り，慣性力 による衝揧を㧕制する必要がある。図13で得られたセンサ 出力曲線の近似曲線式を求め, 害荷重に対し, 検出された カセン井特性を図14に示す。測定結果より，提案する手法 が超磁歪センサのヒステリシス低減に有効であることが分 かった，本実騟においては，サンプリンダ周期を500msとし たが，現状でも数十ms程度の周期までは対応可能である。

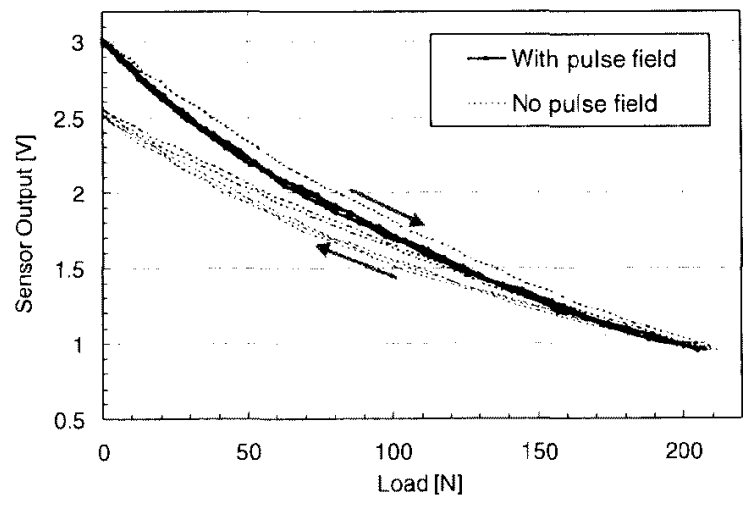

図 13 ヒステリシス低減手法のよるセンサ出力 Fig.13. Characteristics of GMM sensor output utilizing the hysteresis reduction method

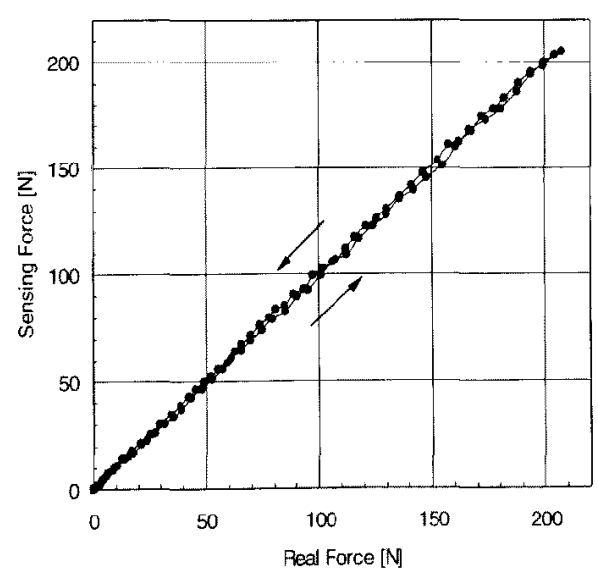

図 14 提案于法による力七ンサヒステリシスの改善 Fig.14. Improvement of GMM force sensor hysteresis 
しかし, インダクタンス変化の検出回路とパルス電流の印 加回路を共用しているため, パルス電流によるセンサ值の 変動が治まるまでの時間は必要であり, 更に高速なサンプ リング周期に対応するためには, 検出用コイルのインダクタ ンス, 励振周波数, フィルタの時定数, 及び, アクチュ エーション用パルス電流のパルス幅といった各パラメータ を調整する必要がある。これらの調整により大規模な構造 の変更やコストアップをすることなく更に高精度な電動ア シスト自転車用踏力トルクセンサに改良することが可能で ある。

\section{5. まとめ}

本論文では, 超磁歪素子を用いた電動アシスト自転車用 トルク(カ)センサの開発内容について示した，更に，超磁 歪素子を用いたセンサ精度の最大の要因となるヒステリシ スを低滅する手法の提案を行った，本研究で得られた諸点 は以下の通りである。

(1) 超磁歪素子の特性を活かした電動アシスト自転車に最適 な弾性変位の無いチェーンホイールー体の超磁歪トルク センサを開発した。

(2) 素子の特徵である高いセンシテビティと耐圧縮応力によ り小型軽量で大容量 $(0 \sim 160 \mathrm{Nm})$ の超磁歪トルクセンサ を実現した。

(3)センサのマイコン機器組み込みを考虑し, ヒンサ值のサ ンプル直前にパルス磁界を印可することにより，ヒステ リシスの低隇が可能であることを検証した。

(4)パルス磁界で素子の内部磁化を一度磁場方向に揃えるこ とによる消磁効果と, 荷重の慣性力により圧縮歪が大き くなることで, センサ感度と非直線性も向上することが 分かった。

(5)一方,パルス励磁によるインパルス音の発生やパルス励 磁電力による電源電力消費の問題もあり,これらの点に 関しては,パルス電流值, パルス幅, およびパルス波形 とセンサのサンプリング周波数を考慮し，更に改良して いく必要がある。

今後, 本トルクセンサの実用化に向けては, 信号伝達部 を含む信頼性の向上と, 個体差によるセンサ特性のばらつ きの抑制が当面の課題であり，これらについて研究を進め ていく予定である．

\section{謝辞}

本研究開発進めるにあたり, 超磁昰素子の提供やご指導 ご助言を頂いたTDK 株式会社基礎材料研究所の森輝夫氏を はじめご協力頂いた皆様に感謝致します。

(平成 13 年 3 月 23 日受付, 平成 13 年 7 月 16 日再受付)

\section{文 献}

（1）長谷川武彦, 中道忍, 勝岡達三, 生熊克己, 柴田広高, 小山 裕之：「電動ハイブリッド自転車の開発」, 機械振興, vol.27,No.12, pp.86-89 (1994)
(2) 芦原安史:「電動ハイブリッド自転車の設計開発における発 想の展開」, 日本機械学会通常総会满演会講演論文集, Vol.72, No.5, PP.383-384 (1995)

（3）木村達郎，手塚義博：「電動補助力付き自転車の駆動系の開 発と設計 自転車のペダルトルク検出手法とリダクションギ アの消音手法」，油空圧技術，Vol.36, No.9, PP.10-14 (1997)

(4) 森輝夫, 石川博康, 中村知子, アメール.ラトール: 超磁歪材 料, 工業材料, Vol.44, No.11, PP.48-53 (1996)

(5) J. L. Butler : "Application Manual for the Design of ETREMA TERFENOL-Dim Magnetostrictive Transducers," pp.7-12,19-26 Edge Technologies, Inc., (1988)

(6) A.E.クラーク，江田弘：超磁歪材料マイクロシステム・ア クチュエータへの応用，日刊工業新聞社，pp.1,85-94,169189 (1995)

(7) H.Wakiwaka, K.Aoki, T.Yoshikawa, H.Kamata, M.Igarashi, H.Yamada : "Maximum output of a low frequency sound source using giant magnetostrictive material, Journal of Alloys and Compounds, Vol.258, pp.87-92 (1997)

（8）村田幸雄, 川瀨和夫, 小川豊, 脇若弘之, 山田一: 「超磁歪 材料の大出カアクチュエータへの適応検討」, 第9 回「電磁 カ関連のダイナミックス」シンポジウム講演会論文集. pp.36 (1997)

（9）森輝夫, 江田弘, 野老誠吾, 清水淳:「超磁歪を用いた圧力 センサの開発」, 日本機械学会生産加工·工作機械部門講演 会講演論文集, Vol.1, pp.209-210 (1999)

（10）森輝夫, Amer Rathore，江田弘:「超磁歪材料を用いた磁歪振 動センサ」，第7回「電磁力関連のダイナミックス」シンポ ジウム講演論文集, No.125,pp.129-130(1995)

（11）角谷和重, 河上日出生, 青木英明：「超磁歪トルクセンサを 用いた電動アシスト自転車の開発」, 第 16 回日本ロボット 学会学術講演会予稿集, pp.1193-1194 (1998)

(12) G. Nick Weisensel : "ETREMA TERFENOL-D Sensor Technology Study," pp. 10;16;21-32 (1996)

(13） Harry E.Burke: 磁気現象ハンドブック, 共立出版株式会社, pp.195-196 (1995)

(14) Kazushige Kakutani, Keiji Kishimoto, et al.:"Study on a Method of Hysteresis Reduction for the Force Sensor using Giant Magnetostrictive Material", Proceedings of the Japan -USA Flexible Automation Conference, 2000JUSFA-13026 (2000)

角谷 和重 (正員) 1964 年 10 月 13 日生まれ。1987年

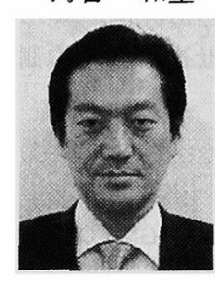
3 月九州工業大学電気工学科卒業. 同年 4 月 三洋電機(株) 入社. 主としてパワーアシス ト制御を用いた介護ロボット，電動アシス 卜自転車の開発, 超磁歪枌料を用いた力七 ンサの研究に従事. 日本ロボット学会, シ ステム制御情報学会会員.

横谷 和展 (正員) 1964 年 10 月 18 日生まれ。1989年

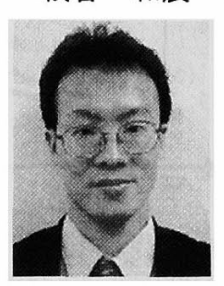
3 月大阪市立大学機械工学科卒業. 同年 4 月 三洋電機 (株) 入社. 主としてパワーアシス ト制御を用いた電動アシスト自転車, 超磁 歪材料を用いた力センサの研究に従事.シ ステム制御情報学会会員. 